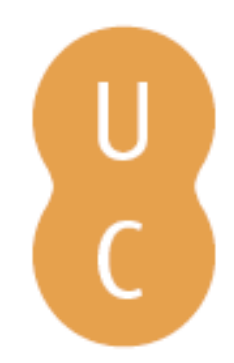

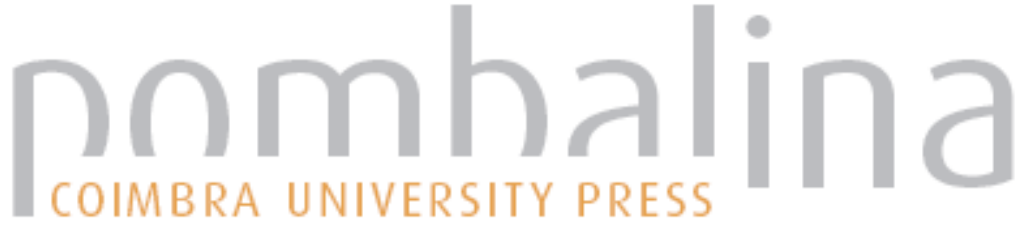

\section{Problemas éticos do uso da genómica individual na investigação criminal}

\author{
Autor(es): $\quad$ Rosa, Bárbara Santa
}

Publicado por: Imprensa da Universidade de Coimbra

URL

persistente: $\quad$ URI:http://hdl.handle.net/10316.2/38509

DOI: $\quad$ DOI:http://dx.doi.org/10.14195/978-989-26-0957-7_7

Accessed : $\quad$ 26-Apr-2023 11:23:41

A navegação consulta e descarregamento dos títulos inseridos nas Bibliotecas Digitais UC Digitalis, UC Pombalina e UC Impactum, pressupõem a aceitação plena e sem reservas dos Termos e Condições de Uso destas Bibliotecas Digitais, disponíveis em https://digitalis.uc.pt/pt-pt/termos.

Conforme exposto nos referidos Termos e Condições de Uso, o descarregamento de títulos de acesso restrito requer uma licença válida de autorização devendo o utilizador aceder ao(s) documento(s) a partir de um endereço de IP da instituição detentora da supramencionada licença.

Ao utilizador é apenas permitido o descarregamento para uso pessoal, pelo que o emprego do(s) título(s) descarregado(s) para outro fim, designadamente comercial, carece de autorização do respetivo autor ou editor da obra.

Na medida em que todas as obras da UC Digitalis se encontram protegidas pelo Código do Direito de Autor e Direitos Conexos e demais legislação aplicável, toda a cópia, parcial ou total, deste documento, nos casos em que é legalmente admitida, deverá conter ou fazer-se acompanhar por este aviso.

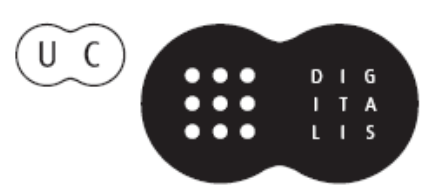




\section{PRINCÍPIOS}

\section{DE GENÉTICA}

\section{FORENSE}

FRANCISCO CORTE-REAL DUARTE NUNO VIEIRA

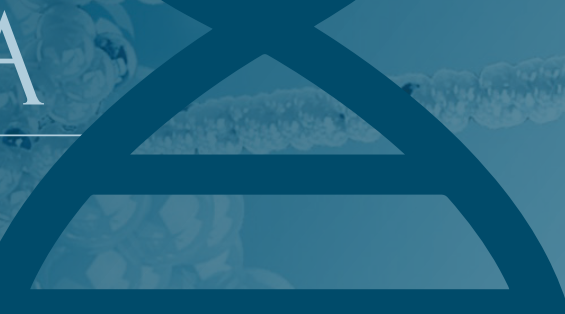

c)
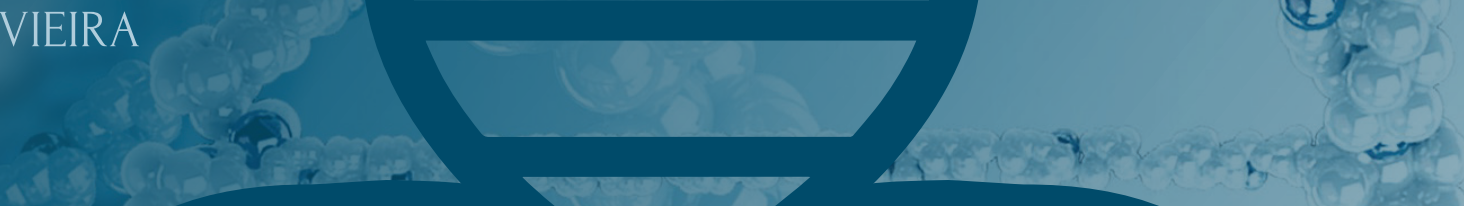

(4)

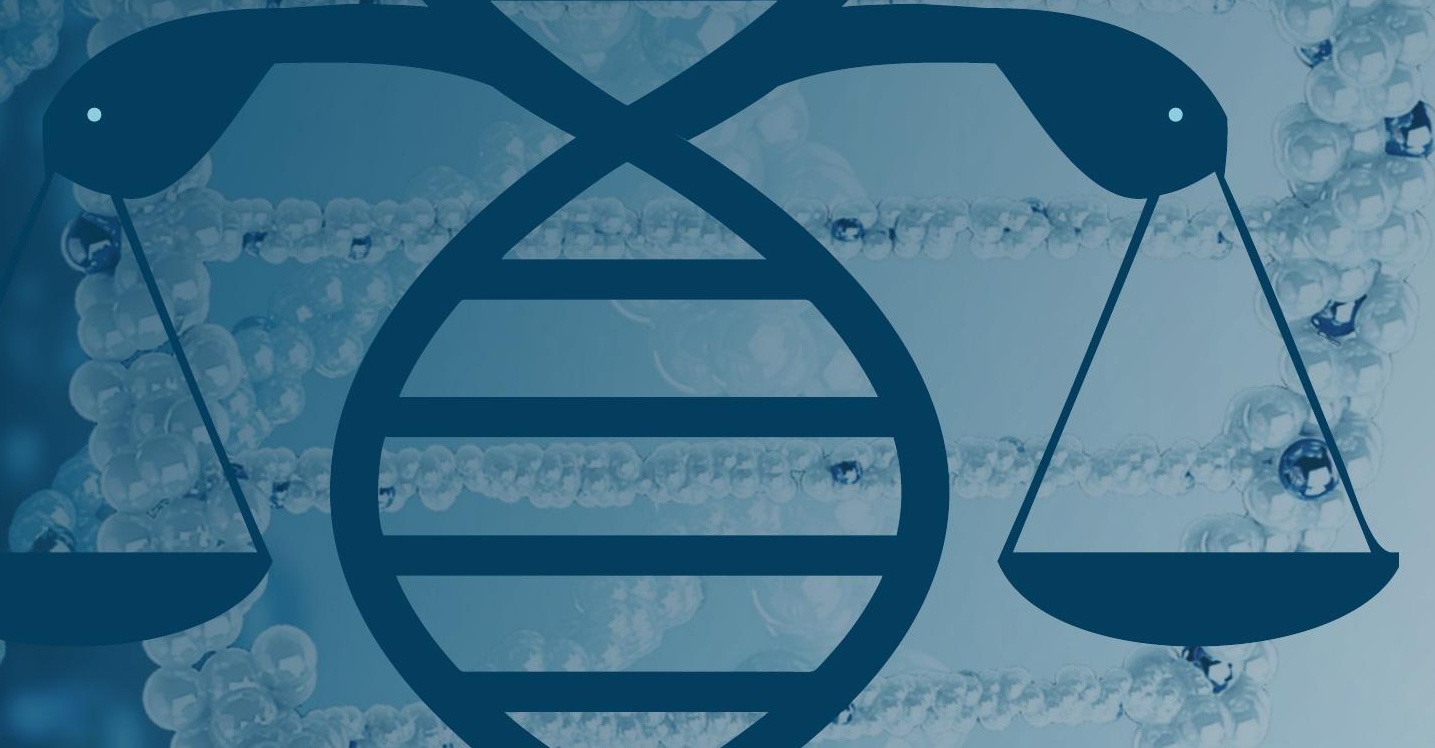

min $2(5)$

Exar. 
Capítulo 7

\section{PROBLEMAS ÉTICOS DO USO DA GENÓMICA INDIVIDUAL NA INVESTIGAÇÃO CRIMINAL}

\section{Bárbara Santa Rosa}




\section{RESUMO}

Em 1985 Alec Jeffreys, utilizando a tipagem de ADN por análise de polimorfismos para fins de identificação individual, afirmou a Genética como disciplina de importância capital na investigação forense. Desde então a crença na infalibilidade da prova genética expandiu-se de forma proporcional ao gradual desenvolvimento das técnicas de análise de ADN com consequente acesso a uma quantidade crescente de informação a partir de uma amostra biológica. Deste facto resultou uma aparente desvalorização de outros métodos de investigação criminal. No entanto, o uso da genómica individual em contexto forense tem, desde logo, lacunas científicas, o que significa que outras metodologias de investigação podem eventualmente revelar-se mais adequadas e eficazes em determinados casos. Acresce que, quando abordamos temas relacionados com a Genética, não podemos negligenciar a sua dimensão ética. São inúmeros os episódios desastrosos que marcaram a história desta disciplina, dos quais sobressai a eugenia nazista.

Nesta conformidade é importante antecipar as possíveis ofensas aos direitos fundamentais e princípios éticos gerais (tais como a liberdade, a privacidade e a autonomia) decorrentes da utilização de tipagem de ADN (com enfoque na pesquisa de factores individualizantes pessoais e/ou populacionais) na investigação criminal. É a este objectivo que se submete este capítulo. Serão nele abordados alguns problemas éticos relacionados com a colheita das amostras biológicas para obtenção do perfil genético e com a utilização desses perfis para comparação identificativa e eventual armazenamento numa base de dados. É, ainda, abordada a possibilidade de recurso, neste âmbito, a outras metodologias de análise de ADN, designadamente à fenotipagem (directa e indirecta).

\section{PALAVRAS-CHAVE}

Autonomia, Ciências forenses, Ética, Investigação criminal, Liberdade, Privacidade, Tipagem de ADN

\section{ABSTRACT}

In 1985 Alec Jeffreys used DNA typing, by analysis of polymorphisms, for individual identification, making Genetics a discipline of core importance in forensic investigations. Since then the belief that genetic evidence is virtually infallible grew in proportion to the progressive development of DNA analysis techniques and consequent access to an increasing amount of information contained in a biological sample. Concurrently there was a significant depreciation of other methods used in criminal investigation. However the use of personal genomics in the forensic field is impaired by scientific gaps, meaning that other investigation methodologies available may eventually prove more appropriate and accurate in certain cases. Moreover when we address issues about Genetics we cannot neglect the ethical dimension of the discussion. There were numerous disastrous moments throughout the history of this discipline, amongst which we highlight the nazi eugenics.

Accordingly it is important to anticipate the possible harms to fundamental rights and ethical principles (such as freedom, privacy and autonomy) that can result from the use of DNA typing (focused on research of personal or population individualizing factors) in criminal investigations. This chapter is subjected to this purpose. Thus we will bring to discussion ethical issues related to the collection of the biological sample to obtain DNA profiles as well as the use of such profiles to comparative identification and possible storage in a DNA databases. It is also covered the possibility of using other methods of DNA analysis in this context such as direct and indirect phenotyping.

\section{KEYWORDS:}

Autonomy, Criminal investigation, DNA typing, Ethics, Forensic sciences, Freedom, Privacy 


\section{INTRODUÇÃO}

Em 1985 Alec Jeffreys, utilizando a tipagem de ADN por análise de polimorfismos para fins de identificação individual, afirmou a Genética como disciplina de importância capital na investigação forense. Mas a molécula de ADN inspira sentimentos paradoxais de admiração e receio... abriu-se assim mais uma caixa de Pandora, da qual se libertaram problemas éticos e ameaças aos direitos humanos! Há que relembrar os inúmeros episódios desastrosos na história da Genética, dos quais sobressai a eugenia nazista. Desde logo, não poderemos negligenciar as possíveis repercussões sociais e éticas negativas desta disciplina, preocupações que se exacerbam quando falamos de investigações sobre a variabilidade genética humana, com enfoque em factores individualizantes pessoais e/ou populacionais. A utilização da Genética para fins de identificação pode colidir com valores éticos incontornáveis, sendo aqui de sublinhar a liberdade, a autonomia, a privacidade e a equidade. Há ainda que contemplar nesta análise vários direitos fundamentais, nomeadamente de autodeterminação corporal e informacional, de privacidade familiar e genética, de presunção da inocência e não auto-incriminação bem como de julgamento justo e igualdade de meios entre a acusação e a defesa.

Os dados genéticos, na legislação portuguesa', enquadram a definição de dado pessoal, conceito que abrange qualquer informação de qualquer natureza (...) relativa a uma pessoa singular identificada ou identificável. Estamos assim perante informação do 'domínio reservado', da

\footnotetext{
1 Lei n. ${ }^{\circ} 67 / 98$ de 26 de Outubro
}

'esfera privada' do indivíduo à qual se deve recorrer ponderadamente. Quando invocados interesses públicos ${ }^{2}$ no geral ou interesses mais específicos tais como a eficiência das investigações criminais poderá a sua utilização ser legítima. Impera que se estabeleça um equilíbrio entre as liberdades pessoais e o bem comum. Quanto maior a ameaça à ordem social mais fortes serão os argumentos a favor da restrição de liberdades individuais, de acordo com princípio da proporcionalidade, tão útil à Ética como ao Direito.

Estes conflitos de interesse entre o indivíduo, o sistema judicial e a comunidade, podem ser avaliados através de diferentes perspectivas éticas. De acordo com a teoria Utilitarista nenhuma atitude ou acção é destituída da noção de consequência, o que aparentemente justifica a aplicação do princípio de maximização do benefício para o máximo de indivíduos. Esta premissa baseia-se no conceito consequencialista que submete o julgamento da justeza de uma acção à sua finalidade. De acordo com esta máxima poderia defender-se o uso da identificação genética em qualquer circunstância, desde que o intuito seja promover o bem comum. No entanto, na sua obra Ensaio sobre a liberdade John Stuart Mill (1859), consagrado defensor desta perspectiva, considera o livre desenvolvimento da individualidade como elemento essencial à felicidade humana. Encontra-se aqui implícito o princípio hedonista que defende que essa felicidade irá consistir unicamente em experiências aprazíveis e não dolorosas, sendo de limitar a interferência (legítima) da opinião colectiva na liberdade individual. Logo,

2 Um interesse só pode ser considerado público quando é mais abrangente que um simples interesse estatal 
apesar do Utilitarismo não privilegiar a análise do grau de importância correspondente aos distintos interesses em conflito, o objectivo de maximizar o bem-estar da maioria, poderá per se estimular esse exercício de equilíbrio.

A perspectiva ética baseada nos deveres tem por base a filosofia de Kant (1785) que contempla o conceito de dever aplicado à realidade do ser humano como ser racional, livre e igual entre os demais. Este filósofo, na obra A metafísica dos costumes inspira-nos a agir apenas segundo máximas que possamos ao mesmo tempo desejar que se tornem lei universal e de tal maneira que usemos a humanidade, na nossa pessoa ou na de qualquer outra, sempre e simultaneamente como um fim e nunca simplesmente como um meio. Assim de acordo com este imperativo categórico as acções que coloquem em causa a dignidade humana não são permitidas, o foco de atenção incide na conduta adoptada e não nas suas consequências. Este ponto de vista exclui nomeadamente a utilização de amostras biológicas colhidas com objectivo clínico, para fins de identificação individual, já que o consentimento não abrange, neste caso, propósitos de investigação forense.

Por outro lado, a perspectiva ética baseada na responsabilidade considera que certos direitos individuais, tais como o direito à vida, são tão importantes que não se podem sacrificar por um bem maior nem submeter-se a interferências coercivas. Outros princípios, apesar de fundamentais, vêem a avaliação da sua importância subjugada à consideração de prioridades, devendo nomeadamente atentar-se aos direitos alheios. De facto, deriva desta perspectiva o corolário de que um direito procede do dever de respeito que ele próprio inspira, existindo uma interdependência entre os direitos individuais e os direitos comunitários. Poderíamos mesmo citar Levinas (1988) que na sua obra Totalidade e Infinito afirma que justificar a liberdade não é demonstrá-la mas torná-la justa. Mas se o valor fundamental da dignidade humana resulta intocável, estabelecer a primazia e o alcance de outros princípios tais como a liberdade, a privacidade e a autonomia, de acordo com o caso em concreto, pode revestir-se de alguma dificuldade. Esta parece, no entanto, a perspectiva que melhor se adapta à discussão sobre se as actuais e potenciais exigências que recaem sobre identificação genética de indivíduos exaltam o agir de acordo com o bem comum ou se turvam em controvérsia e ambiguidade de direcções e motivações.

Será que, tal como no mito grego de Pandora, impera no final a esperança? Esperança de que a Genética Forense, disciplina enraizada na natural curiosidade humana, ilumine conhecimentos novos e verdadeiros, de legítima utilização em nome da Justiça?

\section{O PRINCÍPIO DA PRESUNÇÃO DA INOCÊNCIA}

Consagra a Constituição da República Portuguesa, no número 2 do seu artigo 32, que todo o arguido se presume inocente até ao trânsito em julgado da sentença de condenação. É de sublinhar que aquele sobre quem recai uma acusação tem o direito de exigir provas sólidas da sua culpabilidade, devendo as mesmas ser consideradas de acordo com o princípio in dubio pro reo. De facto, a premissa de Voltaire mais vale arriscarmo-nos a salvar um culpado do que 
condenar um inocente, é equiparável a um princípio constitucional, pelo que não é defensável que a prova genética seja considerada conclusiva ou infalível. O princípio da presunção da inocência obriga não só que a acusação seja capaz de provar para além de qualquer dúvida razoável a culpa do arguido mas também que a existência deste tipo de prova não predisponha per se o julgador a optar pela condenação. O perfil genético deve antes sujeitar-se a uma análise jurídica rigorosa, semelhante à inspirada pelos outros tipos de prova. Neste sentido, o artigo $38^{\circ}$ da lei n. ${ }^{\circ}$ 5/2008 de 12 de Fevereiro afirma que em caso algum é permitida uma decisão que produza efeitos na esfera jurídica de uma pessoa ou que a afecte de modo significativo, tomada exclusivamente com base no tratamento de dados pessoais ou de perfis de ADN.

Também o Conselho Nacional de Ética para as Ciências da Vida (CNECV) se pronunciou sobre esta problemática ${ }^{3}$, considerando que o mito da não infalibilidade da identificação genética pode mesmo comprometer o sucesso da investigação policial. O excesso de confiança no poder identificador do ADN desvaloriza outros métodos de investigação criminal, eventualmente mais fiáveis de acordo com o caso em concreto. Talvez por essa razão haja quem conteste a prova do ADN, aconselhando o seu uso apenas como reforço do veredicto, devendo sempre complementar métodos policiais clássicos de identificação.

No entanto, não devemos submeter esta discussão a uma regra geral. Casos há em que a prova genética é suficientemente robusta,

3 Parecer $n$. $^{\circ} 2$ sobre o regime jurídico da base de dados de ADN permitindo afastar qualquer dúvida razoável e justificar a condenação do arguido. Mas, de acordo com as circunstâncias, o Tribunal deverá manter algum cepticismo, designadamente no que respeita à interpretação de amostras contendo mistura de ADN de dois ou mais indivíduos ${ }^{4}$, de amostras degradadas ${ }^{5}$ ou de amostras com diminuta quantidade de $\mathrm{ADN}^{6}$. De facto algumas destas situações testam a ciência e a tecnologia nos seus limites. É ainda de considerar que a possibilidade de obtenção de um perfil de ADN a partir de uma fracção de nanograma desta molécula pode gerar interpretações erradas, no caso de contaminação ou mesmo focar demasiada atenção em suspeitos cuja associação com o local do crime é meramente circunstancial. As decisões judiciais devem ser cautelosas já que, por exemplo, a existência de um álibi ou a incongruência entre a descrição de uma testemunha e o aspecto físico do arguido poderão ser de relevar. Sempre que oportuno o perito pode (e deve) prestar esclarecimentos em sede de Tribunal.

É ainda de atentar que este tipo de prova deve estar igualmente disponível à defesa e à acusação. Refere a recomendação n. ${ }^{\circ} \mathrm{R}$ (92) 1 do Comité de

4 Quando a proporção da mistura é pelo menos de 3:1, a diferença entre os picos de intensidade das bandas permite distinguir os dois perfis, excepto se um dos componentes da mistura for quase inexistente. A interpretação dos perfis quando a proporção de ADN na amostra é semelhante poderá eventualmente ser possível através da 'subtracção' de um dos perfis, se conhecido

5 A título de exemplo pode não ser possível amplificar todos os marcadores STR preconizados, designadamente por drop-out alélico. O menor número de alelos disponíveis para comparação pode aumentar a probabilidade da amostra corresponder a um indivíduo ao acaso, da população

6 Pode ocorrer drop-out ou drop-in (aparecimento de picos artefactuais) alelico, acrescendo que a possibilidade de corresponder a contaminação é elevada 
Ministros do Conselho da Europa, sobre o uso de análises de ADN na investigação criminal, que estas devem ser também acessíveis à defesa, por decisão de autoridade judicial ou por recurso a perícia privada. Quando a quantidade de material biológico passível de analisar for limitada, deve-se assegurar que os direitos da defesa não são prejudicados. Acrescenta o n. ${ }^{\circ} 3$ do artigo $7^{\circ}$ da Lei de Protecção de Dados Pessoais (LPDP)7 que deve ser permitido o tratamento de dados pessoais, designadamente através da análise de ADN, sempre que necessário à declaração, exercício ou defesa de um direito em processo judicial e for efectuado exclusivamente com esta finalidade. Ou seja, o arguido em processo penal sempre que considere que a prova de ADN é bastante para evidenciar a sua inocência pode solicitá-la (Moniz, 2002).

Apesar do número limitado de condenações resultantes (apenas) de correspondências de perfis de ADN, não é negligenciável que a prova de ADN contribuiu e continuará a contribuir para a detenção de autores de crimes de importante gravidade.

\section{A AUTONOMIA}

Ao princípio da autonomia encontra-se subjacente o conceito de consentimento (informado), o qual legitima condutas entendidas de outra forma como ofensas à liberdade individual. Segundo o CNECV ${ }^{8}$ é imperiosa a obtenção de consentimento sempre que aplicável, ainda que o sujeito em causa seja arguido ou condenado. No âmbito da perícia

7 Lei n. ${ }^{\circ}$ 67/98 de 26 de Outubro

8 Parecer $n$. $^{\circ} 52$ sobre o regime jurídico da base de dados de ADN genética o consentimento pode contemplar não só a colheita da amostra, mas também a inclusão do perfil numa base de dados. Partilhando o ponto de vista de Descartes que considera que age com maior liberdade quem melhor compreende as alternativas em escolha, existe ainda o dever de informar sobre as finalidades da colheita da amostra e se aplicável explicar o conceito de base de dados de ADN, os tipos de investigação possíveis e os seus potenciais riscos e benefícios, as condições e duração do armazenamento da amostra biológica e do perfil, as medidas de segurança que garantem a confidencialidade dos dados bem como a possibilidade de comunicação, às autoridades competentes, dos resultados obtidos através do exame do material genético.

De acordo com o n. 1 do artigo $6^{\circ}$ da lei n. ${ }^{\circ}$ 5/2008, a base de dados de perfis de ADN é construída, de modo faseado e gradual, a partir da recolha de amostras em voluntários, para o que devem prestar o seu consentimento livre, informado e escrito. No entanto a legislação Portuguesa, prevê a obrigatoriedade de inserção na base de dados criminal de todos os perfis de condenados com penas concretas iguais ou superiores a três anos ${ }^{9}$. Decorre ainda da Lei n. ${ }^{\circ}$ 45/2004 que regula o regime jurídico das perícias médico-legais o dever de sujeição a este tipo de exame ${ }^{10}$,

9 Art. 8. $^{\circ}$ Lei n. ${ }^{\circ}$ 5/2008, de 12 de Fevereiro (Recolha de amostras com finalidades de investigação criminal) 2- (...) é ordenada, mediante despacho do juiz de julgamento, e após trânsito em julgado, a recolha de amostras em condenado por crime doloso com pena concreta de prisão igual ou superior a 3 anos, ainda que esta tenha sido substituída.

10 Art. $6^{\circ}$ Lei $n^{\circ}$ 45/2004, de 19 de Agosto (Obrigatoriedade de sujeição a exames) 1- Ninguém pode eximir-se a ser submetido a qualquer exame médico-legal quando este se mostrar necessário ao inquérito ou à instrução de qualquer processo e desde que ordenado pela autoridade judiciária competente, nos 
devendo a perícia genética de pessoa que não tenha prestado consentimento, ser ordenada pelo juiz, tendo em conta o direito à integridade física pessoal e à reserva da intimidade do visado ${ }^{11}$.

Mas importa aqui invocar o artigo $149^{\circ}$ do Código Penal, o qual esclarece que para efeito de consentimento, a integridade física se considera livremente disponível, desde que a ofensa ao corpo ou à saúde não contrarie os bons costumes, tomando-se em conta, nomeadamente, os motivos e os fins do agente ou do ofendido, bem como os meios empregados e a amplitude previsível da ofensa. É verdade que a colheita de amostras biológicas, sem consentimento do titular, desde que ofenda o corpo ou a saúde, independentemente da dor e sofrimento causados, cumpre a factualidade típica de crime de ofensa da integridade física. Mas, por outro lado, não é de negligenciar que as lesões insignificantes ou diminutas, que cumprem o critério de adequação social, como será o caso

termos da lei. 2- Qualquer pessoa devidamente notificada ou convocada pelo Director de Delegação do Instituto ou pelo Coordenador de Gabinete Médico-Legal para a realização de uma perícia deve comparecer, no dia, hora e local designados, sendo a falta comunicada, para os devidos efeitos, à autoridade judiciária competente. 3- (...); Art. $172^{\circ}$ Código de Processo Penal (Sujeição a exame) 1- Se alguém pretender eximir-se ou obstar a qualquer exame devido ou a facultar coisa que deva ser examinada, pode ser compelido por decisão da autoridade judiciária competente 2- Os exames susceptíveis de ofender o pudor das pessoas devem respeitar a dignidade e, na medida do possível o pudor de quem a eles se submeter. Ao exame só assistem quem a ele proceder e a autoridade judiciária competente, podendo o examinando fazer-se acompanhar de pessoa da sua confiança.

11 Art. $154^{\circ}$ Código do Processo Penal (Despacho que ordena a perícia) 1- A perícia é ordenada, oficiosamente ou a requerimento, por despacho da autoridade judiciária (...) 2- Quando se tratar de perícia sobre características físicas ou psíquicas de pessoa que não haja prestado consentimento, o despacho previsto no número anterior é da competência do juiz, que pondera a necessidade da sua realização, tendo em conta o direito à integridade física pessoal e à reserva da intimidade do visado. de um encontrão no meio de uma multidão, não são passíveis de rotulação criminal (Moniz, 2002). Segundo as directivas do Gabinete Parlamentar da Ciência e da Tecnologia do Reino Unido ${ }^{12}$ (2006) a colheita de sangue de um suspeito só pode ser efectuada com o seu consentimento, mas a zaragatoa bucal, por se considerar uma colheita não-íntima dispensa consentimento. No entanto, a realização da referida zaragatoa implica a introdução de um objecto numa cavidade corporal, sendo assim de considerar este argumento frágil. É ainda assim inegável que se presumem contemplados os princípios da proporcionalidade e da adequação. Desde logo, os bens e valores juridicamente tutelados pelo Direito Penal justificam, em regra, restrições à liberdade, integridade física e moral e privacidade das pessoas envolvidas como agentes ou vítimas de um determinado crime $^{13}$. É ainda de atentar que a obtenção da amostra biológica poderá constituir o único meio de prova.

A obrigatoriedade de sujeição à análise de ADN é entendida por alguns autores como atentado ao princípio da não auto-incriminação (nemo tenetur se ipsum accusare), que apresenta como matrizes jurídicas os valores e direitos fundamentais de dignidade humana, liberdade de acção e presunção de inocência. Argui Costa Andrade que as provas obtidas em contravenção deste princípio, configurarão inescapavelmente

12 Parliamentary Office of Science and Technology (POST) The National DNA Database (2006)

13 Nos casos de incumprimento do dever de sujeição a exame o examinando será punido por crime de desobediência; Art. $348^{\circ} \mathrm{CP}$ (Desobediência): 1- Quem faltar à obediência devida a ordem ou a mandado legítimos, regularmente comunicados e emanados de autoridade ou funcionário competente, é punido com pena de prisão até 1 ano ou com pena de multa até 120 dias (...) 
um atentado contra a integridade moral da pessoa, particularmente qualificado, na medida em que redunda na degradação da pessoa em mero objecto ou instrumento contra si própria. Mas em boa verdade a colheita de uma amostra biológica para análise não constitui uma declaração contrária à presunção da inocência já que em momento algum o seu titular é obrigado a reconhecer que praticou determinado facto. Desde logo, estamos perante uma perícia de resultado incerto que tanto pode conduzir à condenação como à absolvição do indivíduo que a ela se sujeita (Fidalgo, 2006).

Para além dos perfis dos condenados com penas concretas iguais ou superiores a três anos, podem igualmente ser utilizados para fins de investigação criminal os perfis de amostras colhidas no local do crime ou cedidas por voluntários que devem prestar o seu consentimento livre, informado e escrito. Assim, o legislador atentando ao conflito entre os interesses do arguido e do sistema judicial, assegurou que os arguidos e os condenados cuja pena não enquadra os requisitos acima expostos, não podem ser considerados como voluntários, ou seja, o seu perfil, ainda que determinado no âmbito da investigação criminal, não pode integrar um ficheiro da base de dados que possibilite a sua utilização para fins de investigação criminal14.

Relativamente à conservação das amostras biológicas, considera o CNECV ${ }^{15}$ que não é

14 Art. 6. ${ }^{\circ}$, Lei n. ${ }^{\circ}$ /2008 (Recolha de amostras em voluntários) 3- 0 arguido na pendência do processo criminal apenas pode ser entendido como voluntário na recolha de amostras que não impliquem a respectiva utilização para fins de investigação criminal

15 Parecer n. 52 sobre o regime jurídico da base de dados de ADN defensável, uma vez feita a tipagem dos marcadores e obtidos os perfis de ADN, a conservação das amostras identificadas. Esta posição prende-se com o perigo de potenciais abusos estatais da existência de um biobanco associado à base de dados. Refere ainda o Conselho que quando tal for indispensável à investigação criminal o problema poderá, em parte, solucionar-se com a conservação separada, por entidades diferentes, de amostras e perfis genéticos. De acordo com a Lei n. ${ }^{\circ}$ 5/2008 de 12 de Fevereiro ${ }^{16}$ as amostras de voluntários e pessoas condenadas em processo-crime são destruídas imediatamente após a obtenção do perfil de ADN e as amostras problema provenientes do local do crime são eliminadas quando identificadas com o arguido, no termo do processo-crime ou no fim do prazo máximo de prescrição do procedimento criminal, previsto no Código Penal.

\section{A PRIVACIDADE INDIVIDUAL}

Segundo a legislação portuguesa qualquer informação de qualquer natureza, relativa a uma pessoa singular identificada ou identificável é um dado pessoal, enquadrando o perfil genético esta definição. Apesar de não ser possível a

16 Art. 34. ${ }^{\circ}$ Lei n. ${ }^{\circ}$ 5/2008 de 12 de Fevereiro (Destruição das amostras) 1- As amostras são destruídas imediatamente após a obtenção do perfil de ADN, nos casos das alíneas a) e e) do n. 1 do artigo $15 .^{\circ} 2$ - As amostras colhidas ao abrigo do disposto no n. ${ }^{\circ} 1$ do artigo $8 .^{\circ}$ só podem ser utilizadas como meio probatório no respectivo processo 3- As amostras referentes aos casos previstos nas alíneas $b$ ), c), d) e $f$ ) do $n$. ${ }^{\circ}$ 1 do artigo $15 .^{\circ}$ são destruídas, respectivamente, nos prazos previstos no.$^{\circ} 1$ do artigo $26 .^{\circ} 4$ - O conselho de fiscalização comunica ao presidente do INML para que este ordene a destruição imediata das amostras, quer as mesmas estejam nos respectivos serviços ou em entidade protocolada. 
identificação directa do titular do perfil de ADN através da base de dados, existe um número de código que possibilita aceder aos dados de identificação correspondentes. Decorre igualmente da legislação que o consentimento informado é condição sine qua non para a legitimidade do tratamento de dados pessoais, acrescentando a Constituição da República Portuguesa o direito dos cidadãos acederem aos dados informatizados que lhes dizem respeito e conhecerem a finalidade a que se destinam, nos termos da lei ${ }^{17}$.

Assume-se, no entanto, possível que certas disposições legais possam estabelecer, de alguma maneira, excepções a tais princípios. Exemplo disso é a base de dados de perfis de ADN para fins de investigação criminal, que contraria não só o respeito pela autonomia e consentimento informado, mas também o direito de privacidade. A criação

17 Art. $35 .^{\circ}$ Constituição da República Portuguesa (Utilização da informática) 1- Todos os cidadãos têm o direito de acesso aos dados informatizados que Ihes digam respeito, podendo exigir a sua rectificação e actualização, e o direito de conhecer a finalidade a que se destinam, nos termos da lei 2- A lei define o conceito de dados pessoais, bem como as condições aplicáveis ao seu tratamento automatizado, conexão, transmissão e utilização, e garante a sua protecção, designadamente através de entidade administrativa independente 3- A informática não pode ser utilizada para tratamento de dados referentes a convicções filosóficas ou políticas, filiação partidária ou sindical, fé religiosa, vida privada e origem étnica, salvo mediante consentimento expresso do titular, autorização prevista por lei com garantias de não discriminação ou para processamento de dados estatísticos não individualmente identificáveis 4- É proibido o acesso a dados pessoais de terceiros, salvo em casos excepcionais previstos na lei 5- É proibida a atribuição de um número nacional único aos cidadãos 6- A todos é garantido livre acesso às redes informáticas de uso público, definindo a lei o regime aplicável aos fluxos de dados transfronteiras e as formas adequadas de protecção de dados pessoais e de outros cuja salvaguarda se justifique por razões de interesse nacional 7- Os dados pessoais constantes de ficheiros manuais gozam de protecção idêntica à prevista nos números anteriores, nos termos da lei desta base de dados não contempla os conceitos de sigilo ou anonimato no seu sentido lato, já que tem um objectivo a eles contrário, permitir a identificação dos titulares da informação nela introduzida (eventualmente sem consentimento).

Relativamente à colheita de amostras biológicas, o Tribunal Europeu dos Direitos do Homem ${ }^{18}$, considera que uma intervenção médica compulsiva, mesmo que de pouca relevância, ${ }^{19}$ deve considerar-se uma limitação ao respeito pela vida privada ${ }^{20}$. No entanto as recomendações do Conselho da Europa não proíbem o recurso à coacção na recolha forense de amostras, desde que as circunstâncias o justifiquem ${ }^{21}$. Há ainda que atentar ao $\operatorname{artigo} 3^{\circ}$ da Convenção Europeia dos Direitos do Homem ${ }^{22}$ que condena o recurso à violência, neste contexto (excepto se estritamente necessária à detenção do indivíduo). No entanto, as repercussões do uso da força teriam que ser suficientemente importantes para contrariar o princípio instituído neste artigo, facto improvável quando falamos na recolha de amostras

18 Caso Peters v Netherlands

19 Nomeadamente a colheita de urina para pesquisa de drogas ilícitas

20 Art. $8^{\circ}$ da Convenção Europeia dos Direitos do Homem estatui que cada pessoa tem direito ao respeito da sua vida privada e familiar, do seu domicílio e da sua correspondência e ainda que não pode haver ingerência da autoridade pública no exercício deste direito senão quando esta ingerência estiver prevista na lei e constituir uma providência que, numa sociedade democrática, seja necessária para a segurança nacional, para a segurança pública, para o bem-estar económico do país, a defesa da ordem e a prevenção criminal, a protecção da saúde ou da moral, ou protecção dos direitos e das liberdade de terceiros.

21 Recomendação n. ${ }^{\circ}$ R (92) 1 do Comité de Ministros do Conselho da Europa, sobre o uso de análises de ADN na investigação criminal

22 Art. $3^{\circ}$ Convenção Europeia dos Direitos Humanos (Proibição de tortura) Ninguém pode ser submetido a torturas, nem a penas ou tratamentos desumanos ou degradantes 
por zaragatoa bucal. Desde logo, não devemos subestimar o n. 2 do artigo $8^{\circ}$ da Convenção que assume como prioridades assegurar a segurança nacional e a segurança pública, prevenir a criminalidade e respeitar os direitos e liberdades de terceiros.

Outro ponto que importa discutir quando falamos de privacidade é o período de tempo que o perfil de STR, do condenado, permanece na base de dados criminal. Há quem defenda que estes perfis deviam constar na base ad eternum, considerando expectável um aumento da probabilidade de obter correspondências com as amostras provenientes de locais de crime. De acordo com esta perspectiva, os indivíduos com uma condenação prévia são mais propensos ao crime que aqueles nunca antes condenados. Poderíamos ainda justificar este ponto de vista argumentando que os indivíduos previamente condenados, em virtude dos crimes que cometeram, não são dignos dos mesmos direitos dos cidadãos cumpridores, tornando-se juridicamente defensável admiti-los como os suspeitos "do costume" (Murphy, 2010). É igualmente comum o argumento de que um ex-condenado poderá mesmo beneficiar da permanência do perfil na base de dados. No caso de crimes de tendência repetitiva, tais como abuso sexual, se o indivíduo se mantiver cumpridor da lei, sempre que na sua área de residência ocorra um crime sexual em que haja prova biológica, será imediatamente ilibado sem constrangimentos de inquérito policial e/ou detenção temporária.

No entanto, define a legislação portuguesa ${ }^{23}$ que os perfis inseridos na base de dados criminal

23 Art. 26. ${ }^{\circ}$ Lei n. ${ }^{\circ}$ 5/2008 de 12 de Fevereiro (Conservação de perfis de ADN e dados pessoais) 1 - Os perfis de ADN e os correspondentes dados pessoais são: (...) d) Eliminados, quando a amostra for identificada com o arguido, no termo devem ser eliminados no fim do prazo máximo de prescrição do procedimento criminal. Como já referido, um dos componentes do princípio de privacidade é o anonimato, ou seja, o direito do indivíduo não ser sujeito a uma vigilância estatal ou social excessiva. É este anonimato que permite às famílias e aos indivíduos não ver o seu futuro degradado por escolhas erradas passadas, mantendo a possibilidade de ingressar em novos projectos ou novas relações. Citando Orwell (1949), na sua obra 1984, quem controla o passado, controla o futuro. De igual forma não deve ser vedada a oportunidade de reabilitação e reinserção social àqueles com um passado criminal já que em termos práticos a retenção dos perfis por tempo indefinido aumenta a vigilância dos seus titulares, mantendo a seu nome (in)directamente associação ao crime cometido.

Apesar da natural controvérsia sobre a forma como deve ser regulamentada a base de dados criminal é inegável o seu importante papel na promoção de interesses públicos tais como a dissuasão criminal, a prevenção da repetição de condutas ilegais e a confirmação não só da culpa mas também da inocência dos suspeitos.

\section{A PRIVACIDADE FAMILIAR}

Se quisermos ser mais precisos, a informação genética não é um simples dado pessoal, é antes um dado familiar, tendo como titular toda a família e não uma pessoa singular²4 (H. Moniz,

do processo-crime ou no fim do prazo máximo de prescrição do procedimento criminal, previsto no Código Penal (...)

24 Este facto pode também colocar algumas dúvidas sobre a validade do consentimento, mesmo que se trate de um consentimento livre e esclarecido 
2002). Assim quando o perfil da amostra biológica proveniente do local do crime não encontra correspondência (em todos os alelos dos marcadores STR), quando cruzada com os perfis da base de dados é possível pesquisar a existência de correspondências parciais, que denunciem eventuais laços familiares biológicos ${ }^{25}$ entre o suspeito e os titulares dos perfis da base (Smith et al., 2012). De facto, os familiares em primeiro grau partilham aproximadamente metade dos alelos dos marcadores STR, sendo que pais e filhos têm em comum pelo menos um dos alelos de cada marcador. Familiares ligeiramente mais afastados (avós e netos, tios e sobrinhos) partilham cerca de um quarto dos alelos do perfil.

Historicamente as autoridades policiais sempre investigaram relações familiares, sem encontrar grande resistência na opinião pública. Se a descrição de uma testemunha ocular permitir identificar um suspeito, vindo-se a comprovar que o mesmo tem um álibi passível do excluir como autor do crime, será absurdo não colocar como hipótese que algum familiar, nomeadamente um irmão, possa apresentar igualmente traços fenotípicos compatíveis com os realçados no retrato robot. Surge ainda como inegável que entrevistar possíveis familiares de um suspeito, que eventualmente se encontram na posse de informação privilegiada, pode ser essencial à investigação. O recurso à base de dados, para pesquisa familiar, poderia então ser encarado como uma evolução natural de métodos mais tradicionais. No entanto

25 O CODIS contém uma ferramenta intitulada Pesquisa Familiar, actualmente não utilizada em Portugal para fins de investigação criminal, no entanto é já utilizado noutros países, nomeadamente nos Estados Unidos da América e no Reino Unido, apresentando taxas de sucesso de 10-14\% (Gershaw et al., 2011) esta abordagem reveste-se de limitações não só do ponto de vista científico mas também do ponto de vista legal (Kayser et al., 2011).

Desde logo, da pesquisa resultam habitualmente correspondências parciais com vários perfis constantes na base de dados, ou seja, é identificado um conjunto de eventuais familiares do suspeito. De facto, a probabilidade de dois indivíduos terem um perfil de STR correspondente em determinado número de loci é considerável (Smith et al., 2012). Pelo contrário, a força probatória de uma correspondência completa reside na improbabilidade (muitas vezes expressa por uma razão de verosimilhança de um para vários milhões ou biliões) da correspondência se dever à existência de outra pessoa exactamente com o mesmo perfil. Acresce que quando se estabelece como possível uma relação familiar entre o suspeito e um indivíduo cujo perfil consta na base de dados, obrigar esse indivíduo (inocente daquele crime em concreto) a ceder informações de filiação é uma limitação importante à sua privacidade, podendo mesmo ser questionável se tal conduta se enquadra no dogma de ultima ratio, característico do Direito Penal. A este respeito, não devemos no entanto deixar de considerar que podem ser tomadas medidas para minorar intrusões desnecessárias na vida privada tais como, recorrendo ao exemplo da realidade Californiana, a avaliação da adequação geográfica entre a área de residência do suposto familiar do suspeito e a zona onde foi cometido o crime, bem como a estrutura e o passado criminal da família em causa. Também o facto do suposto familiar se encontrar sob custódia judicial à data da investigação criminal poderá, de alguma maneira, tornar 'mais' legítima esta abordagem (Gershaw et al., 2011). 
Não é igualmente de negligenciar o risco desta ferramenta de análise de ADN, tendo em conta as suas importantes limitações, contribuir para a sobrevalorização da prova genética em detrimento de outros métodos de identificação tradicionais, por ventura mais adequados ao caso em concreto. Desta sobrevalorização poderá resultar visão em túnel, denunciada pela incúria ou inércia na procura de elementos probatórios alternativos (Murphy, 2010). E mesmo em casos em que não existem alternativas viáveis para chegar à identificação do suspeito, se o mesmo não for familiar de nenhum dos indivíduos que têm o perfil na base de dados, o recurso a esta pesquisa servirá apenas para diminuir artificialmente o conjunto de possíveis culpados. A título de exemplo 57\% dos indivíduos acusados de crime de abuso sexual, num ano, nunca terão sido detidos ou condenados anteriormente (Smith, 2006). Poderíamos mesmo ir mais longe, afirmando a pesquisa de filiação biológica como arbitrária e discriminatória, baseando-se na premissa de que os familiares de alguém com um passado criminal têm maior probabilidade de cometer um crime do que os familiares de um qualquer cidadão cumpridor da lei. Efectivamente, há quem recorra a este argumento para defender o recurso à pesquisa familiar (Bieber et al., 2006), mas tendo em conta variáveis como o tipo de conduta e as circunstâncias em que ocorreu, é difícil assumir a existência de uma tendência criminal familiar. Não é portanto defensável considerar que os familiares de alguém, cujo perfil consta na base de dados, são 'mais' suspeitos que os familiares de outro indivíduo qualquer, sendo que estes dois grupos se distinguem apenas por um 'acaso biológico' ou um 'azar de filiação'. Impera que os benefícios e incómodos da existência da base de dados criminal se diluam por toda a sociedade, sendo contrário à equidade a sua concentração em determinados grupos populacionais.

Outro ponto a considerar é a possível revelação de relações familiares biológicas, ou da sua ausência, desconhecidas ou omitidas intencionalmente no seio familiar. A possível inserção do perfil dos condenados na base de dados sem o seu consentimento exacerba este problema. Importa assim que a informação familiar, obtida com recurso à base de dados, permaneça confidencial26. Deve igualmente assegurar-se que entidades com fins alheios à investigação criminal não têm acesso aos perfis constantes na base, nomeadamente o Tribunal de Família, para a resolução de casos de filiação biológica.

Há a concluir que mesmo considerando que os direitos fundamentais de privacidade/ intimidade e autodeterminação informacional não têm carácter ilimitado, podendo ceder em nome de interesses comunitários (Moniz, 2002) e que os conflitos descritos podem ser suavizados restringindo-se o recurso a este método de acordo com directivas legais que atentem à

26 Art. 28. ${ }^{\circ}$ Lei n. ${ }^{\circ}$ 5/2008 de 12 de Fevereiro (Dever de segredo) 1- A comunicação ou a revelação dos dados pessoais, bem como dos perfis de ADN, mesmo que não identificados, registados na base de dados, só pode ser efectuada nos termos previstos na presente lei e no estrito cumprimento das normas constantes da Lei da Protecção de Dados Pessoais 2Os responsáveis pelo processo relativo à colheita de amostras e à obtenção do perfil, bem como pela inserção, comunicação, interconexão e acesso aos ficheiros que contêm os perfis de ADN ou dados pessoais, ficam obrigados a sigilo profissional, mesmo após o termo das suas funções 3- Igual obrigação recai sobre os membros do conselho de fiscalização, mesmo após o termo do mandato 
opinião pública, a utilização desta ferramenta de pesquisa deve considerar-se apenas como último recurso, nomeadamente nos casos em que a amostra biológica é a única prova passível de permitir a identificação do suspeito ${ }^{27}$. Mas, ainda que o recurso a esta ferramenta cumpra os critérios legais de proporcionalidade, pode ainda assim ser entendida como inconstitucional, contrariando os critérios jurídicos de inclusão na base de dados criminal. De facto a pesquisa familiar vai permitir, de forma subtil, o aumento da inclusividade da base de dados, bem como tornar mais abrangente o tipo de informação possível de obter através dos marcadores STR, escolhidos pela sua suposta 'inutilidade'.

Em boa verdade, se a identificação indirecta de um suspeito através de perfis de indivíduos que sabemos inocentes, é percebida pela comunidade como sendo benéfica, não seria uma alternativa óbvia e justa criar uma base de dados Nacional/ Universal?

27 Há ainda a contemplar outras possibilidades, nomeadamente à análise de marcadores haplótipos do cromossoma Y. Estes marcadores são transmitido por linha paterna, à semelhança do sobrenome, de acordo com a realidade portuguesa, podendo o seu estudo ser revelador deste importante dado individualizante. King et al. (2006) realizou um estudo, no Reino Unido, e verificou que com esta metodologia é possível determinar correctamente o sobrenome do suspeito em $19 \%$ dos casos, sendo a percentagem mais elevada quando o último nome em causa é incomum. Também neste tipo de pesquisa se levantam as questões de privacidade familiar discutidas, falhando a inferência sempre obviamente que o sobrenome do indivíduo não reflicta um laço familiar biológico. Podemos ainda evocar que exames genéticos de marcadores do cromossoma $Y$ podem inadvertidamente denunciar deleções genéticas associadas nomeadamente a infertilidade. Este facto remete-nos novamente para a discussão acerca do acesso arbitrário a informação médica individual.

\section{A PRIVACIDADE gENÉTICA}

Excluindo o facto do perfil de STR denunciar o género do seu titular, este não se relaciona directamente com características fenotípicas do indivíduo. Os loci de ADN utilizados são designados não codificantes ou inúteis, ou seja, à luz dos conhecimentos actuais não lhes é atribuível uma função. Sublinha o CNECV ${ }^{28}$ que caso seja encontrada uma associação entre um marcador não codificante utilizado no perfil e uma doença ou um traço comportamental, esse marcador deverá ser retirado do painel e todos os dados que tenham sido obtidos anteriormente com esse marcador deverão ser eliminados.

Mas com o gradual desenvolvimento das técnicas de análise de ADN é possível aceder a uma quantidade crescente de informação pessoal a partir de uma amostra biológica. Assim, tendo em conta o limitado alcance da base de dados criminal na identificação de suspeitos, aos problemas já discutidos soma-se a preocupação de que, no futuro, haja pressão para expandir o espectro das análises genéticas da amostra biológica proveniente do local do crime à fenotipagem.

\section{FENOTIPAGEM INDIRECTA}

Da hiperactividade da ciência resultou já a possibilidade de inferir a ancestralidade do titular de uma amostra a partir do perfil de STR, com base em estudos de frequências alélicas populacionais ${ }^{29}$. Com a aplicação informática

28 Parecer $n .^{\circ} 52$ sobre o regime jurídico da base de dados de ADN

29 Fonseca et al (2011) Supplement for 'On using machine learning to predict the affiliation of an individual to a major 
PopAffiliator ${ }^{30}$, é possível traduzir o número de repetições de cada alelo nos loci dos 17 marcadores STR autossómicos, habitualmente analisados na perícia Genética em Portugal, por probabilidades de pertença, do titular da amostra, a cinco grandes grupos populacionais ${ }^{31}$. Esta análise de inferência biogeográfica permite ter uma noção, ainda que muito vaga, da provável aparência do titular da amostra, enquadrando o conceito de fenotipagem indirecta. Mas considerando a ubiquidade alélica populacional (mesmo quando falamos de polimorfismos STR), o valor preditivo deste tipo de análise não é, para já, satisfatório (Shriver et al., 2005 e Kayser et al., 2011).

No entanto, alguns polimorfismos de nucleótido único (SNP), pertencentes a loci codificantes da molécula de ADN, apresentam frequências significativamente diferentes em grupos populacionais distintos, sendo denominados de marcadores informativos da ancestralidade (MIA). É de referir, a título de exemplo, que determinados alelos associados a doenças raras existem apenas num determinado grupo populacional ou familiar, podendo ser utilizados para fins de identificação forense $^{32}$ (Bobadilla et al., 2002; Loader et al., 1996). Mas também aqui recorremos à fenotipagem indirecta, considerando que se o titular da amostra pertence a um determinado grupo

population group based on a forensic based set of autosomal STR' disponível para consulta em http://cracs.fc.up.pt/ nf/popaffiliator2/

30 http://cracs.fc.up.pt/ nf/popaffiliator2/

31 Ásia, Eurásia, África sub-Saariana, Norte de África, Médio Oriente

32 Foram já identificados cerca de 1000 alelos do Gene Regulador da Condução Transmembrana da Fibrose Quística (CFTR), a maioria deles existindo numa única família ou num pequeno grupo de indivíduos populacional devemos assumir que ele partilha as suas características fenotípicas. Este tipo de inferência reveste-se de muita fragilidade, já que os vínculos existentes entre o genótipo e o fenótipo são ardilosos. De facto, o conhecimento da ancestralidade nem sempre providencia uma inferência fiável da aparência do indivíduo e nem sempre o fenótipo permite determinar de forma consistente a ancestralidade. Parra et al. (2003) estudaram uma amostra de indivíduos de nacionalidade Brasileira, constatando que dos indivíduos classificados como "definitivamente caucasóides" (por análise visual de dois peritos), cerca de um quarto apresentava uma proporção de ancestralidade genética Africana ou Ameríndia superior a 50\%. Da mesma forma, indivíduos classificados como "inequivocamento negróides" apresentavam preponderância genética Europeia. Decorre do exposto que o recurso a este tipo de dados deve ser cauteloso, podendo mesmo funcionar como factor de distracção na investigação criminal, criando expectativas ilusórias relativamente ao fenótipo do agente do crime. Sublinha-se no entanto que a crítica recai mais uma vez sobre a fenotipagem indirecta, não obstante poder ser útil o conhecimento da procedência biogeográfica do suspeito à investigação em curso.

De facto, com a natural diminuição dos custos e das barreiras tecnológicas, se a implementação deste tipo de testes aparentemente aumentar a eficácia da investigação criminal as pressões para o seu uso rotineiro serão enormes. Uma hipótese seria invocar aqui o princípio da proporcionalidade, afirmando que de acordo com a gravidade da conduta e os bens jurídicos ofendidos se poderia justificar uma análise 'mais completa' da amostra biológica proveniente do local do crime, desde que 
tais dados pudessem apenas servir a investigação criminal que tornou legítima a sua obtenção. Mas há que observar cum grano salis esta possibilidade, já que o estudo genético da ancestralidade com aplicação forense se reveste não só de problemas práticos, mas também conceptuais. De facto, um debate multidisciplinar entre historiadores, antropólogos, biólogos e eticistas tomou conta da problemática do recurso a informações sobre ancestralidade genética na investigação criminal.

Duster (2006) invoca a possibilidade do conceito de ancestralidade genética poder reforçar ou recriar o estereótipo de que as minorias são perigosas e moralmente inferiores. Ossorio (2006) vê com alguma ansiedade a associação entre afinidade populacional, genes e crime, sublinhando que o carácter probabilístico/orientador da inferência biogeográfica possa ser mal interpretado, legitimando que as minorias comunitárias sejam o principal alvo da justiça. Esta problemática tem pouco de original, ao longo do século XIX muitos foram os investigadores (Cartmill, 1998) que procuraram padrões de diferenças entre indivíduos com distintas afinidades populacionais. Esta taxonomia racial devia considerar características tais como o comprimento dos membros, a cor da pele e a textura capilar. Já no século Xx tornou-se evidente a impossibilidade de chegar a um consenso sobre a existência de raças humanas, dado que as fronteiras antropométricas bem definidas entre populações, apanágio de tal conceito, se esbateram à medida que o número de indivíduos, características e locais geográficos estudados se acumulou. A constatação da possibilidade de utilização do genoma humano para fins de identificação individual, parece erradamente ter animado expectativas de que a 'tal' essência racial residisse na molécula de ADN.
Mas o conceito de raça alimenta-se não só de factores biológicos, mas também sócio-culturais, pelo que é complexo e mutável, não definível pelo estudo de marcadores genéticos (Pilar, 2006). Na realidade, a espécie humana é demasiado recente para acumular diferenças genéticas substanciais. Não obstante o facto de que grupos populacionais próximos geograficamente apresentem mais semelhanças genéticas entre si do que quando comparados com populações longínquas. Jorde et al. (2004) afirmam que a variabilidade genética surge de forma contínua e sobreponível nas várias populações. Assim, com o intuito de evitar a confusão entre o conceito de ancestralidade e o conceito racial, os investigadores aconselham que os resultados da fenotipagem indirecta sejam apenas geográficos (Kayser et al., 2011).

Também não devemos descurar o facto dos dados genealógicos disponíveis às famílias serem, na grande maioria dos casos, escassos e superficiais, com possibilidade de recuar apenas algumas gerações. Um teste genético de ancestralidade pode revelar informações que o individuo desconhece sobre si mesmo ou que ocultou intencionalmente, configurando eventualmente uma experiência desconcertante ou mesmo estigmatizante.

\section{FENOTIPAGEM DIRECTA}

Mas cientificamente ainda não esgotámos todas as alternativas ${ }^{33}$, restam os SNPs que

33 Pode-se ainda recorrer ao ADN mitocondrial, que é apenas transmitido pela mãe (não recombinante). O perfil de ADN mitocondrial pode ser rastreado por várias gerações através dos familiares maternos, já que apesar de mutações pontuais que ocorrem ao longo de período de tempo considerável, a sequência permanece muito semelhante. Não permite no entanto fazer pesquisas familiares já que indivíduos não rela- 
codificam características físicas de forma directa e permitem uma fenotipagem igualmente directa. O estudo de associação global do genoma ${ }^{34}$ é um procedimento validado para identificar loci responsáveis pela variação de características poligénicas correlacionando o genótipo de milhares de SNP com fenótipos de interesse tais como pigmentação do cabelo, olhos e pele. De todos os traços físicos estudados até agora a cor dos olhos é o mais fiável, existindo já um kit para uso forense, denominado IrisPlex ${ }^{\circledR}$, que possibilita perceber qual a proporção probabilística do titular da amostra apresentar íris de cor verde ou castanha (Walsh et al., 2011).

Mas também este tipo de análise não passa de uma previsão já que a precisão da inferência de uma característica fenotípica através do genótipo depende do número de SNP que contribuem de forma independente para essa característica e de influências ambientais (Kayser et al., 2011). Conclui-se então que mesmo no auge do seu potencial a genética forense nunca produzirá uma imagem do titular da amostra estudada comparável com uma fotografia. De facto, as descrições geneticamente baseadas não identificam um suspeito em particular mas uma população de suspeitos. Ainda assim, tendo em conta a notória falta de exactidão de outros métodos de identificação alternativos, este método não precisa

cionados familiarmente podem partilhar o mesmo ADN mitocondrial desde que partilhem um ascendente feminino muito tempo atrás. Por outro lado, a uniformidade geracional do ADN mitocondrial permite assim que este seja usado para determinar a ancestralidade de uma forma muito fiável, podendo-se chegar ao país de origem geográfica do suspeito. Este tipo de exame de ADN foi já considerado como prova em julgamentos nos EUA e é usado pelo FBI para obtenção de perfis (Smith, 2006).

34 GWAS; Genome-wide asociation studies ser especialmente específico ou exacto para se considerar satisfatório e pode eventualmente providenciar um meio útil e idóneo de avaliar a fiabilidade das descrições de testemunhas oculares ou outros tipos de profiling, nomeadamente psicológico.

Actualmente o desenvolvimento de características psicológicas e de psicopatologia não é bem compreendido (Jacob et al., 2005; Hariri et al., 2002; Kandel et al., 2001). Pensa-se que a genética, neste campo, exerce uma influência de cerca de $50 \%$, sendo os factores ambientais responsáveis pelo resto. Este facto não impede que existam já profecias sobre o possível uso da amostra encontrada no local do crime para obter perfis psicológicos, tomando em conta a associação existente entre psicopatologia e comportamento criminal (Smith, 2006).

Tornam-se assim evidentes diversos problemas de cariz ético, quando falamos do uso de ADN para fins de identificação, não por comparação de perfis mas por análise directa dos seus loci codificantes. De relance a informação genética sobre o fenótipo do indivíduo pode não parecer tão sensível como a informação médica. Podemos mesmo argumentar que este tipo de informação pessoal é visível ou de fácil acesso. Mas não nos precipitemos! O estudo dos SNP pode revelar várias informações pessoais em simultâneo. Ou seja, um alelo associado à cor da pele pode também denunciar predisposição genética para determinada doença, isto porque os genes podem participar activamente em diversas vias metabólicas. Acresce que muitos MIA se associam directamente à propensão ou manifestação patológica.

Para além de questões relacionadas com a privacidade e a autodeterminação informacional, 
já que grosso modo quanto mais individualizante, íntima e pessoal for a informação obtida através da perícia genética, maior a sua utilidade, poderemos ainda invocar a problemática da discriminação ${ }^{35}$. Harris et al. (1999) identificaram algum enviesamento no tratamento de minorias populacionais pelas forças de segurança pública. Após consulta dos registos policiais relativos ao controlo do trânsito, verificou-se que os indivíduos 'latinos' e 'negróides' tinham uma probabilidade oito vezes maior de serem parados em operações stop do que os 'caucasóides'. Há quem defenda que a aplicação destes testes genéticos poderia contribuir para a igualdade de tratamento das minorias populacionais, substituindo-se o preconceito pelos dados decorrentes da análise científica ${ }^{36}$. Por outro lado, sempre que o teste genético apontasse o suspeito como membro de uma minoria esse facto seria mais facilmente percebido como justo pela comunidade em questão.

No entanto, se a análise genética revelar que o seu titular pertence ao grupo populacional dominante essa informação será, obviamente, de menor utilidade do que se, pelo contrário, estabelecer uma relação com uma minoria. Será portanto pouco provável que o problema da discriminação

35 Refere o artigo $14^{\circ}$ da Convenção Europeia dos Direitos do Homem (sobre proibição de discriminação) que o gozo dos direitos e liberdades reconhecidos na presente Convenção deve ser assegurado sem quaisquer distinções, tais como as fundadas no sexo, raça, cor, língua, religião, opiniões políticas ou outras, a origem nacional ou social, a pertença a uma minoria nacional, a riqueza, o nascimento ou qualquer outra situação.

36 M'Charek (2008) descreve um caso em que uma criança de 16 anos foi assassinada numa cidade Holandesa, tendo o estudo genético da ancestralidade revelado a origem ocidental/europeia do culpado. A população enfurecidamente convicta de que o crime tinha sido cometido por um dos indivíduos provenientes do norte de áfrica ou do médio oriente residentes na hospedaria local, viu assim o seu ânimo acalmado. encontre aqui uma resposta definitiva. Por outro lado, se assumirmos a existência de uma taxa de crime desproporcionadamente elevada nos grupos populacionais minoritários seria plausível assumir que a fenotipagem, aumentando o número de detenções, logo a segurança, poderia beneficiar tais comunidades. Mas será que os benefícios hipotéticos superam os possíveis danos?

De acordo com a Recomendação n. ${ }^{\circ} \mathrm{R}(97) 5$ do Comité de Ministros do Conselho da Europa, sobre a protecção de dados clínicos, a perícia genética deve apenas ser usada para fazer prova, no contexto de uma ofensa criminal. Em nenhum caso deve ser usada para determinar outras características de cariz genético. Consta ainda na Resolução do Conselho Europeu de 25 Junho de 2001, relativa à partilha de resultados de análises de ADN que os Estados-Membro devem limitar o intercâmbio às zonas do cromossoma sem expressão genética.

Neste sentido, apesar de grande parte dos países Europeus, designadamente Portugal, não possuir legislação específica sobre a fenotipagem, na prática a genética forense analisa apenas loci de ADN não codificantes. A lei Belga assume que o único propósito da perícia genética no âmbito da investigação criminal é a comparação de perfis de ADN para, directa ou indirectamente identificar o perpetrador ou a vítima. O uso do ADN para outro tipo de análise genéticas encontra-se tipificado como crime. A Holanda surge como único país Europeu que tem uma lei específica sobre fenotipagem, tendo acrescentado ao seu Código de Processo Penal, em 2003, a possibilidade de determinar características físicas visíveis desde o nascimento, a partir de uma amostra biológica encontrada no local do crime e pertencente a um suspeito desconhecido (Koops et al., 2008). 
Apesar de todos os problemas apontados é de admitir a fenotipagem como uma alternativa importante quando não existem outras formas de se identificar o suspeito. No futuro a análise de ADN vai tornar-se mais fiável e detalhada, alargando-se o espectro de características identificáveis. Tão pouco é possível excluir, com toda a certeza, que marcadores genéticos até agora considerados inúteis possam indirectamente influenciar ou programar a expressão genética. Há assim que regular o uso destas ferramentas, considerando sempre que a ciência pode eminentemente mudar de paradigma. Seria importante regular o recurso à fenotipagem, atentando à opinião pública e legislações já implementadas, nomeadamente a Holandesa. Consta da recente revisão Australiana do crimes act (1914) que as legislações não devem encarar de forma proibitiva o recurso às tecnologias de análise de ADN, devendo no entanto ser aplicadas após escrutínio público. Uma abordagem proactiva desta temática pela lei penal poderia, por um lado, prevenir a absolvição de culpados por inadmissibilidade de provas-chave em Tribunal e por outro evitar violações desnecessárias da privacidade dos suspeitos.

\section{BASE DE DADOS UNIVERSAL, UTOPIA OU DISTOPIA?}

As bases de dados de ADN representam um exemplo de associação entre novas e eficazes formas de controlo social a estratégias político- governamentais de controlo do crime. Rabinow (1996), epígono de Foucault, no seu ensaio sobre a antropologia da razão, chamou à sobreposição entre os conceitos social e vital biossocialidade, que considerou de importância capital na biopolítica, termo que decorre da atenção dada pelo governo à vida humana, no seu sentido biológico. Existe assim importante relação entre a biossocialidade e o biopoder (a administração da vida) que apesar de simbiótica não deixa de suscitar alguma controvérsia, nomeadamente no que diz respeito aos usos sociais da genética. Mais recentemente Lynch e McNally (2008) surgem como autores do conceito biolegalidade, representativo da relação de cooperação entre a lei e a biotecnologia, sendo perceptível neste contexto um processo contínuo de redefinição dos direitos e do estatuto do corpo do suspeito e da credibilidade da prova criminal. De facto, o armazenamento de perfis de ADN numa base de dados é um poderoso instrumento de biovigilância. É importante introduzir na discussão o princípio da equidade, sendo nomeadamente de assegurar que os critérios de inclusão (de cariz mutável) na base de dados criminal, não possibilitem uma distribuição desigual de grupos comunitários em si representados, evitando assimetrias populacionais de vigilância governamental. Orwell no ensaio 'A Política e a língua inglesa' (1946) enquadra a equidade numa lista de palavras às quais são atribuíveis diferentes significados, muitos deles esquivos. De facto o autor tinha já sublinhado na sua obra 'Triunfo do Porcos' (1945) que 'os animais são todos iguais, mas uns são mais iguais que outros'.

A este propósito Alec Jeffreys referiu na Conferência Anual da Sociedade Britânica de Genética Humana, no ano de 2001, que a criação de uma base de dados universal é a forma mais ética de armazenar os perfis, anulando muitas das questões relacionadas com a discriminação e com a privacidade. Desde logo eliminava-se 
a possibilidade da base representar desproporcionalmente diferentes grupos populacionais. Acresce que a expansão da base permitiria que os perfis de STR fossem suficientes para identificar os titulares das amostras encontradas nos locais dos crimes, inutilizando o recurso à fenotipagem em contexto forense (Williams et al. 2004).

Mas o conceito de base de dados universal pode pôr em causa o princípio jurídico da proporcionalidade, já que da importante restrição de liberdade e autonomia individual resultará um pálido aumento da segurança pública. Há ainda que atentar a questões de injustiça distributiva, pois o investimento humano e económico necessário para criar uma base de dados universal é desproporcionado relativamente aos ganhos expectáveis ${ }^{37}$ sendo de considerar que na ausência de meios para garantir boas condições de vida ao conjunto da população, não é defensável tal investimento.

Também não deve ser negligenciada a possibilidade de que, nomeadamente, disputas políticas propiciem a utilização desadequada desta informação. Sublinha o $\mathrm{CNECV}^{38}$ que a informação contida na base de dados pode ser usada para estudos forenses e mesmo para estudos epidemiológicos desde que se assegure o anonimato irreversível dos dados, não sendo, no entanto, aceitável o uso de amostras associadas à obtenção de perfis para investigação biomédica.

Há ainda quem sublinhe que a criação de uma base de dados universal expressa uma

37 Alguns autores propõem como solução que a tipagem fosse realizada ao nascimento. É igualmente de admitir uma gradual diminuição do custo analítico por indivíduo incluído na base de dados, ao longo do tempo.

38 Parecer $n .^{\circ} 52$ sobre o regime jurídico da base de dados de ADN violação de importantes princípios constitucionais, passando-se a considerar todos os indivíduos como possíveis perpetradores de crimes. De facto, haverá uma obrigatoriedade de toda a população se sujeitar a análise genética, independentemente de suspeita criminosa. Mas não pode deixar de ser referido que a nossa legislação prevê esta possibilidade, nomeadamente no Código da Estrada ${ }^{39}$ que prescreve que o condutor ou a pessoa que se propôs a iniciar a condução, apesar de não ser arguido ou suspeito num processo-crime, tem que se submeter a exames de determinação da taxa de alcoolemia. É de relembrar que nos casos em que seja impossível proceder a pesquisa de álcool no ar expirado verifica-se a obrigatoriedade de sujeição a punção venosa para colheita de sangue.

Mas, independentemente dos prós e dos contras despertados pela base de dados universal, a tendência é que os critérios de inclusão, excepção a excepção, se vão tornando mais abrangentes. Em boa verdade, o Reino Unido dispõe já de uma base de dados nacional. Justifica-se aqui citar José Saramago: de que adianta falar de motivos, às vezes basta um só, às vezes nem juntando todos ${ }^{40}$.

39 Art. $152^{\circ} 1$-Devem submeter-se às provas estabelecidas para a detecção dos estados de influenciado pelo álcool ou por substâncias psicotrópicas a) os condutores; b) os peões, sempre que sejam intervenientes em acidentes de trânsito; c) as pessoas que se propuserem a iniciar a condução 2-(...) 3- as pessoas referidas nas alíneas a) e b) do $n^{\circ} 1$ que recusem submeter-se às provas estabelecidas para a detecção do estado de influenciado pelo álcool ou por substâncias psicotrópicas são punidas por crime de desobediência 4-(...) 5- O médico ou paramédico que, sem justa causa, se recusar a proceder às diligências previstas na lei para diagnosticar o estado de influenciado pelo álcool ou por substâncias psicotrópicas é punido por crime de desobediência

40 Em Jangada de Pedra (1986) 


\section{BIBLIOGRAFIA}

Bieber, F. et al., (2006). Fiding criminal through DNA of their relatives. Science, 312, 1315-1316.

Bobadilla, J. et al., (2002). Cystic Fibrosis: A worldwide analysis of CFTR mutations: Correlation with incidence data and application to screening. Human Mutation, 19, 575-606.

Cannold, L., (2008). Who's the father? Rethinking the moral 'crime' of 'paternity fraud'. Women Studies International, 31, 249-256.

Castmill, M., (1998). The status of the race concept in physical anthropology. American Anthropologist, 100, 651-660.

Cho, M. \& Sankar, P., (2004). Forensic genetics and ethical, legal and social implications beyond the clinic. Nature (Genetics), 36, 8-12

Duster, T., (2006). The molecular reinscription of race: unanticipated issues in biotechnology and forensic science. Patterns of prejudice, 40, 427-441.

Fidalgo, S., (2006). Determinação do perfil genético como meio de prova em processo penal. Revista Portuguesa de Ciência Criminal, 16, 115-148.

Ford, P., (2010). DNA Forensic Procedures: Further independent reviewof part 1D of the Crimes Act 1914 Forensic Procedures. Commonwealth Attorney-Gneral's Department.

Gershaw, C., Schweighardt, A., Rourke, L. \& Wallace, M., (2011). Forensic utilization of familial searches in DNA databases. Forensic Science International Genetics, 5, 16-20.

Guillén, M. et al., (2000). Ethical-legal problems of DNA databases in criminal investigation. Journal of Medical Ethics, 26, 266-271.

Hariri, A. et al., (2002). Serotonin transporter genetic variation and the response of the human amygdala. Science, 297, 400-403.

Harris, D., (1999). The statistics and the law: Why 'driving while black' matters. Minnesota Law Review, 84, 265-326.

Hepple, B. et al., (2007). The forensic use of bioinformation: ethical issues, Nuffield Council on Bioethics.

Jacob, C. et al., (2005). Cluster B personality disorders are associated with allelic variation of monoamine oxidase A activity. Neuropsychopharmacology, 30, 1711-1718.

Jorde, L. \& Wooding, S., (2004). Genetic Variation, Classification and 'Race'. Nature Genetics, 36, 28-33.
Kandel, E., (2001). The molecular biology of memory storage: A dialogue between genes and synapses. Science, 294, 1030-1038.

Kayser, M. \& Knijff, P., (2011). Improving human forensics trough advances in genetics, genomics and molecular biology. Nature Reviews Genetics, 12, 179-192.

Kelves, D., (1985). In the Name of Eugenics. Berkeley: University of California Press.

King, T., Ballereau, S., Schurer, K. \& Jobling, M., (2006). Genetic signatures of coancestry within surnames. Current Biology, 16, 384-388.

Koops, B. \& Schellekens, M., (2008). Forensic DNA phenotyping: regulatory issues. Columbia Science Technology an Law Reviews, 9, 158-202.

McCartney, C., (2006). The DNA expansion programme and criminal investigation. British Journal of Criminology, Volume 16, pp. 115-148.

M'Charek, A., (2008). Silent witness, articulate collective: DNA evidence and the inference of visible traits. Bioethics, 22, 519-528.

McNally, R. \& Lynch, M., (2008). DNA, Biolegality and Changing Conceptions of Suspects. Genomics Forum, University of Edinburgh.

Moniz, H., (2002). Os problemas jurídico-penais da criação de uma base de dados. Revista portuguesa de Ciência Criminal, 2, 237-264.

Murphy, E., (2010). Relative doubt:familial searches of DNA databases. Michigan Law Review, 109, 291-348.

Ossorio, P., (2006). About Face:Forensic Genetic Testing for Race and Visible Traits. Journal of Law, Medicine \& Ethics, 277-292.

Parra, F. \& al, e., (2003). Color and genomic ancestry in Brazinlians. Proceedings of the National Academy of Sciences, 100, 177-182.

Perisco, N. \& Castleman, D., (2005). Detecting Bias: Using statistical evidence to establish intentional discrimination in racial profiling cases. The University of Chicago Legal Forum.

Loader, S. et al., (1996). Cystic Fibrosis Carriaer Population Screening in the Primary Care Setting. American Journal of human Genetics, 59, 234-247.

Shriver, M., Frudakis, T. \& Budowle, B., (2005). Getting the science and the ethics right in forensic genetics. Nature Genetics, 37, 449-451. 
Smith, M., (2006). Let's make the DNA identification database as inclusive as possible. Journal of Law, Medicine \& Ethics, 385-389.

Smith, M. \& Urbas, G., (2012). Regulating new forms of forensic DNA profiling under Australian legislation: familial matching ans DNA phenotyping. Australian Journal of Forensic Sciences, 44, 63-81.

Walsh, S. et al., (2011). IrisPlex: A sensitive DNA tool for accurate prediction of blue and brown eye colour in the absence of ancestry information. Forensic Science International Genetics, 5, 170-180.

Williams, R. \& Johnson, P., (2004). 'Wonderment and dread': representation of DNA in ethical disputes about forensic DNA databases. New Genetics and Society, 23, 205-223.

Yao, Y. et al., (2002). Phylogeographic differentiation of mitochondrial DNA in Han Chinese. American Journal of Human Genetics, 70, 365-648. 